\title{
STUDIES OF PALEOZOIC SEED FERNS: ADDITIONAL STUDIES OF MICROSPERMOPTERIS APHYLLUM BAXTER
}

\author{
K. B. PIGG,$*$ R. A. STOCKEY, $\dagger$ AND T. N. TAYLOR* \\ *Department of Botany, Ohio State University, Columbus, Ohio 43210; and $\doteqdot$ Department of Botany, University \\ of Alberta, Edmonton, Alberta, Canada T6G 2E9
}

\begin{abstract}
The genus Microspermopteris is characterized as a small lyginopterid pteridosperm with a pentarch protostele, irregular cortical ridges, and multicellular trichomes. We describe the frond architecture and variability among axillary branches previously unknown for the genus. Fronds are small and delicate, exhibiting three orders of branching. Clasping V-shaped petioles produce primary pinnae alternately to suboppositely from adaxial projections. Primary pinnae in turn produce secondaries that bear two-, three-, or four-lobed ultimate laminar pinnules. Pinnules reconstructed from serial sections are morphologically similar to Sphenopteris-like compressions; however, the overall frond is reduced in size and complexity. While some axillary branches produce secondary xylem, others are composed entirely of primary tissues. Some axillary branches produce scalelike leaves in a tight helix; distally, immature buds are surrounded by flattened bud scales. Although Microspermopteris shows similarities to Heterangium in stelar and cortical anatomy, the two taxa are distinct. Microspermopteris is interpreted as a delicate, scrambling vine, liana, or shrublike plant in contrast to the more robust lyginopterids Lyginopteris, Schopfiastrum, and Heterangium.
\end{abstract}

\section{Introduction}

Among the Paleozoic pteridosperms, the Lyginopteridales represent some of the stratigraphically oldest, simplest, and most primitive forms. The group was established conceptually with the reconstruction of Lyginopteris by OLIVER and SCOTT (1904) from disarticulated organs in coal balls. Associated organs from the same permineralized sources were thought to represent parts of the same plant, based on capitate glands and dictyoxylon cortex that occurred in the isolated plant parts. At our current level of understanding, lyginopterids, including such genera as Heterangium Corda, Schopfiastrum Andrews, and Microspermopteris Baxter, are generally considered as small, scrambling lianas or possibly shrubs (PHILLIPS 1980) rather than arborescent forms. Although we now recognize more than a dozen ovules, several types of pollen organs, and perhaps five major stem genera within the order Lyginopteridales from permineralized remains alone (PHILLIPS 1980; TAYLOR and MILlay 1981), many questions remain unanswered concerning the morphology, affinities of disarticulated organs, and whole-plant reconstructions of these plants.

Perhaps one of the most enigmatic seed ferns is Microspermopteris. Specimens of Microspermopteris are known sporadically from a variety of middle Pennsylvanian localities on the midcontinent and in the Appalachian Basin. Specimens have been described from the Copland coal of Kentucky (Lewis Creek) (TAYLOR and STOCKEY 1975, 1976),

Manuscript received April 1985; revised manuscript received September 1985.

Address for correspondence and reprints: T. N. TAYLOR, Department of Botany, Ohio State University, 1735 Neil Avenue, Columbus, Ohio 43210 .
Mineral and Bevier Coal Members in Kansas, and the Murphysboro equivalent, Colchester and Summum coals in the Illinois Basin (MAHAFFY 1975). The holotype, $M$. aphyllum, was described from What Cheer, Iowa (Des Moines Series) (BAXTER 1949). Additional material was later described by BAXTER (1952) from the Fleming coal of Kansas. Microspermopteris-like plants are also known from the Bouxharmant Seam in Europe (PHILlips 1980) and from Britain in the Lancashire Coal Measures at Shore near Littleborough, where they were described as Syncrama (HoLDEN 1954). Not until the 1970s, however, was sufficient material available to characterize many anatomical features of the genus (MAHAFFY 1975; TAYLOR and STOCKEY 1975. 1976).

BAXTER (1949) instituted the taxon M. aphyllum for anatomically preserved stems of middle Pennsylvanian age that were up to $2.5 \mathrm{~mm}$ in diameter. Stems are characterized by a pentarch, exarch mixed protostele frequently surrounded by secondary $\mathrm{xy}$ lem. The stem exhibits a two-zoned cortex with horizontally aligned sclerotic plates in the outer zone. prominent cortical ridges that give it an irregular outline, and multicellular epidermal appendages or trichomes. BAXTER (1949) reported the presence of what he interpreted as distichous branching, but the apparent absence of leaves or fronds led him to consider Microspermopteris a leafless pteridosperm intermediate between the psilophytes and other seed plants.

From a large collection of specimens, primarily from Lewis Creek, Kentucky, TAYLOR and STOCKEY (1976) emended the generic diagnosis to include larger stems up to $1.1 \mathrm{~cm}$ in diameter. From these specimens it was determined that the plant exhibited frondlike leaves, borne in a $2 / 5$ phyllotaxy. The petiole traces, petioles, and primary pinna traces 
of Microspermopteris were illustrated (TAYLOR and STOCKEY 1976); however, frond architecture and ultimate laminar segments remain poorly known.

Our study, based on permineralized plants from Lewis Creek, provides an opportunity to characterize several additional features of Microspermopteris, including the anatomy and morphology of foliage and axillary branches. A new reconstruction of the plant is presented. This additional information clearly indicates that Microspermopteris and Heterangium, two genera that have been confused in the past, may now be regarded as distinct taxa on the basis of a suite of anatomical and morphological features.

\section{Material and methods}

The study is based on 25 specimens of Microspermopteris, including stems with petioles, fragments of primary pinnae, secondary pinnae, and the ultimate laminar units. In addition, eight axillary branches were studied in detail. Anatomically preserved material considered in this study occurs in coal balls collected at Lewis Creek, Leslie County, Kentucky. Stratigraphically the locality is regarded as either uppermost lower Pennsylvanian (GOOD and TAYLOR 1970) or lowermost middle Pennsylvanian (PHILLIPS 1980).

Specimens were prepared using standard cellulose acetate peels mounted on microscope slides. Compression specimens of Sphenopteris sp., illustrated for comparative purposes (figs. 24, 25), were collected from gray shales ca. $4 \mathrm{~m}$ beneath the Taylor coal along Lewis Creek (STUBBLEFIELD et al. 1982). This compression locality is geographically separated by ca. $0.5 \mathrm{~km}$ from the coal ball site. Slides and peels of Microspermopteris and of the Sphenopteris compression specimens are stored in the Paleobotanical Collections, Ohio State University, and bear acquisition nos. 6489-6912, 12177-12466, 13554-13723, 16948-17104, and P32-937. The type specimen of Syncrama liratum Holden was examined for comparative purposes. This specimen is housed in the British Museum (Natural History) where it bears collection no. V. 31899 .

\section{Systematics}

MICROSPERMOPTERIS APHYLLUM

Baxter, R. W. 1949. Ann. Mo. Bot. Gard. 36:287-352

Baxter, R. W. 1952. Trans. Kans. Acad. Sci. 55:101-103

TAylor, T. N., and R. A. Stockey. 1976. Am. J. Bot. 63:1302-1310

AMPLIFIED DIAGNOSIS.-Microspermopteris aphyllum Baxter emend. Taylor et Stockey, s. ampl. Pigg, Stockey, et Taylor. (New features are italicized). Stems up to $1.1 \mathrm{~cm}$ in diameter with mixed exarch protostele of large metaxylem tracheids and up to 10 peripherally positioned protoxylem strands. Primary xylem pentagonal in cross section and divided into five sections by longitudinal parenchyma plates that radiate from stem center; protoxylem strands occur in pairs, one strand on each side of a parenchyma plate. Metaxylem tracheids elongate, scalariform or with multiseriate bordered pits. Secondary vascular tissues well developed, secondary xylem tracheids with uni- and multiseriate bordered pits. Xylem rays up to two cells wide. Cortex of thin-walled parenchyma with secretory cells in younger stems and peripherally disposed longitudinal sclerenchyma; periderm of thick-walled radially aligned cells. Stem surface ornamented by longitudinal flaps of cortical tissue, and multicellular, typically flattened trichomes. Petioles arranged in $2 / 5$ phyllotaxy, with single trace slightly $\mathrm{C}$-shaped with abaxial protoxylem; petiole base large and clasping up to one-half stem circumference. Frond consisting of three orders of branching; primary pinnae produced alternately by petiole; secondaries produced alternately on primary pinnae; secondaries bear two-, three- or fourlobed laminar pinnules; foliage parenchymatous with no differentiation into palisade and spongy regions; some specimens with scattered resinous cells; frond resembling reduced, highly dissected Sphenopteris compression foliage. Axillary branches with or without abundant secondary xylem; primary body 85-270 $\mu \mathrm{m}$ in diameter; sometimes producing scalelike leaves in tight helix; bud scales with thinwalled tissue, resinous cells, and sclerotic cells; immature buds enclosed in flattened bud scales distally. Triarch to polyarch adventitious roots, some with secondary tissues, arising at both nodal and internodal regions.

\section{Observations}

\section{GENERAL FEATURES}

Microspermopteris is characterized by a pentarch, mixed protostele often surrounded by secondary xylem, and sometimes producing a small amount of periderm (TAYLOR and STOCKEY 1976). In some specimens the cortex contains abundant, scattered resinous cells that may have been secretory. Stems exhibit epidermal emergences and irregular cortical flanges (fig. 1) and follow a sinuous course through the coal ball matrix. A combination of taphonomic and morphological factors may be responsible for the difficulty with which specimens can be traced in the matrix. Anatomical and morphological features suggest that the plant was a highly parenchymatous, vinelike, or shrubby form that may have wilted and become contorted in the peat prior to fossilization.

The plant is characterized by relatively long internodes with small, slender fronds consisting of 


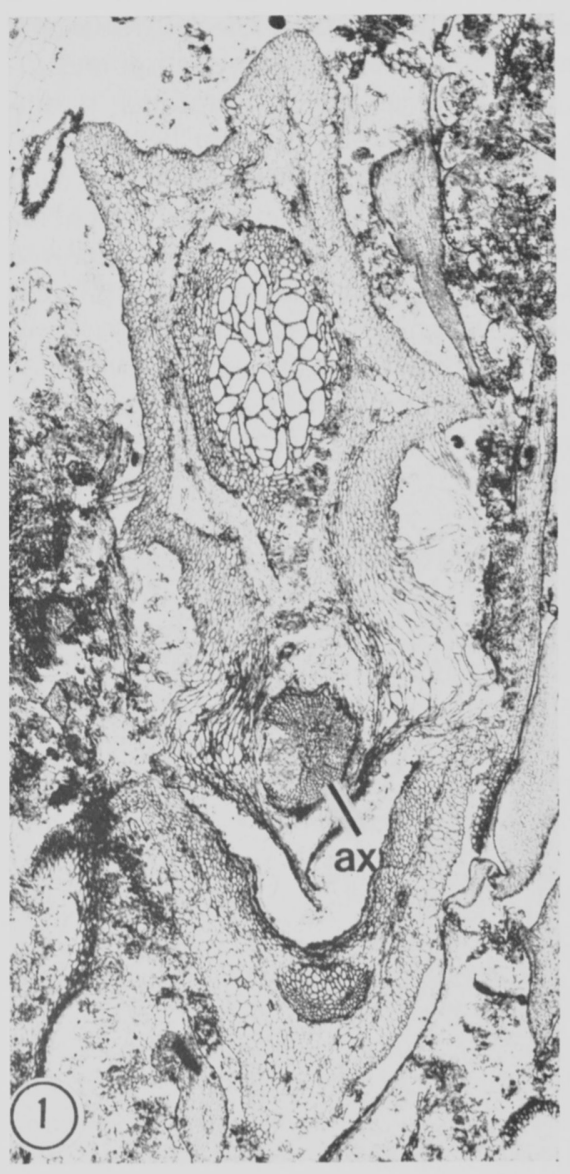

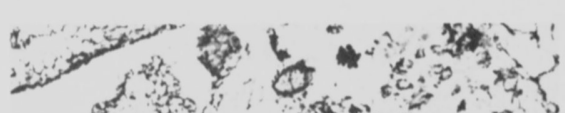

(1) 1

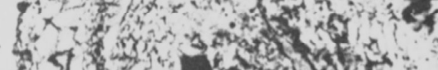

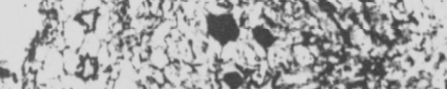

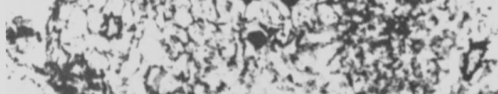

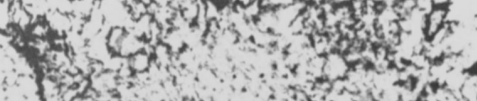

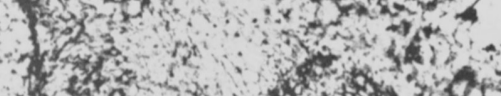

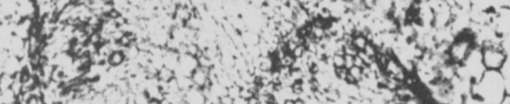

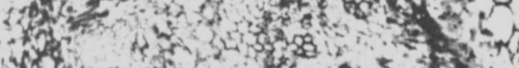
$3040-5,53$ (3) ont on

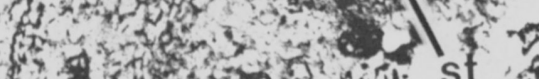

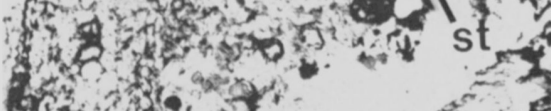
(x) $x+533-20$ (5) 4042
1. 10y

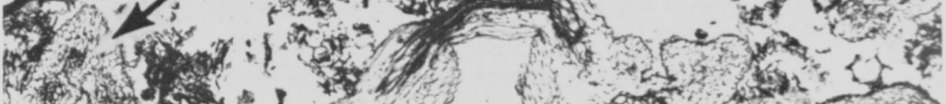

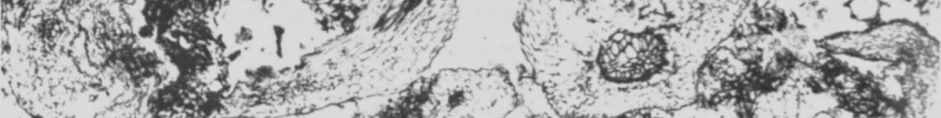

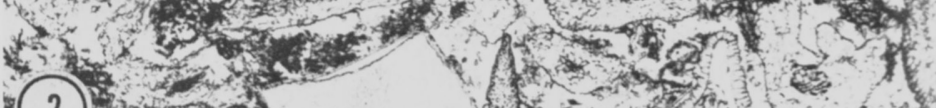

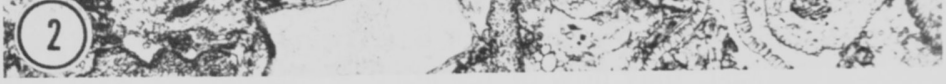

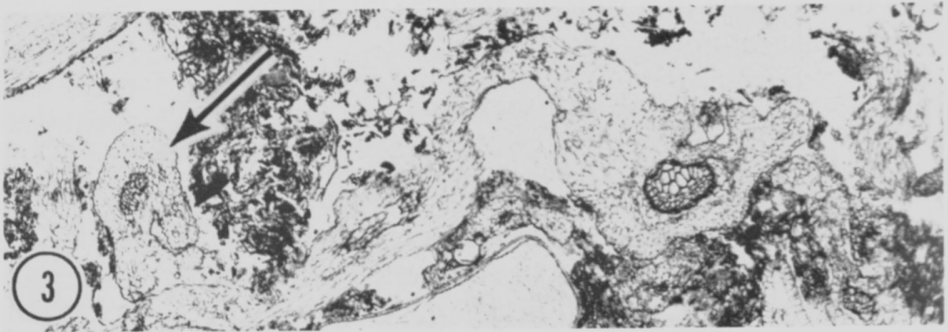

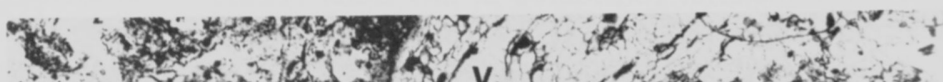

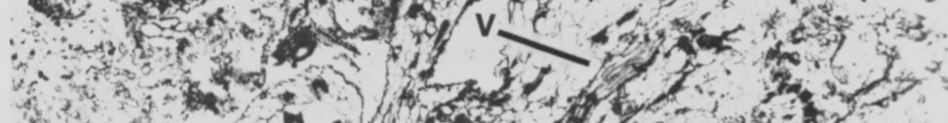

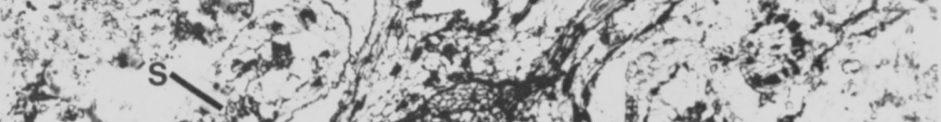

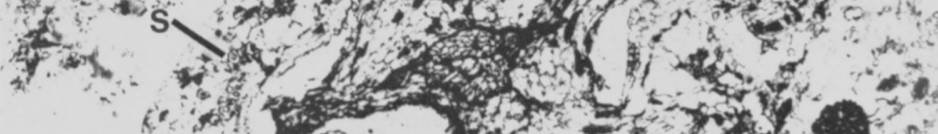

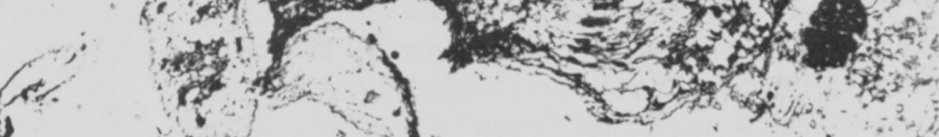

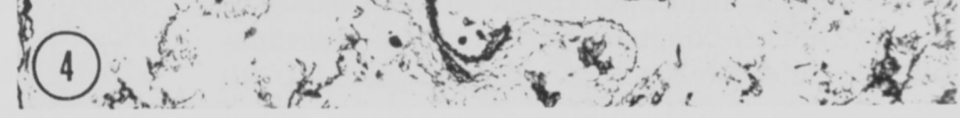

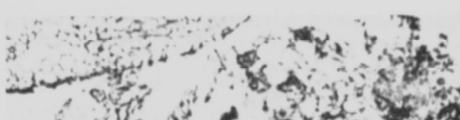
4 ,

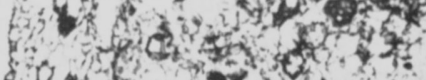
Lo b t

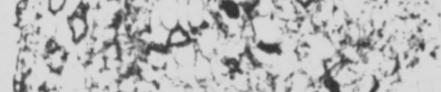
(2) (3) 3 on the

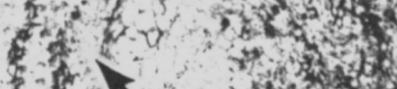

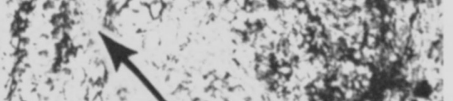

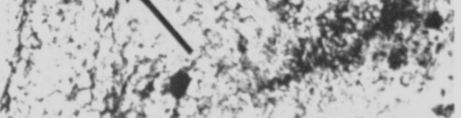
(6) 3 (a) branch $(a x)$. Note prominent cortical wings on stem and radially aligned tracheids of axillary branch. $198 \mathrm{~B}$ bot. no. $206 . \times 20$. (arrows). Fig. 2 is distal to fig. 3. In fig. 2, vascular trace has dichotomized in ultimate laminar pinnule (arrow). $6057 \mathrm{C}$ top b divergence of near-radial vascular trace $(v$, at right) and small groups of sclerotic cells $(s)$ in otherwise parenchymatous tissue 
petioles (figs. 1, 8) bearing alternately to suboppositely arranged primary pinnae (figs. 2, 3, 817). These in turn bear secondaries (figs. 2, 9, 10) that branch into ultimate laminar segments that are two-, three-, or four-lobed (figs. 2, 3, 9, 13, 18$23,26)$. Branches are borne in the axils of petioles. Some exhibit a large $(270 \mu \mathrm{m}$ in diameter $)$, relatively undifferentiated primary body (figs. 57), while in others a small stele is surrounded by radial files of tracheids (fig. 1). Cortical tissue is parenchymatous and irregularly lobed and occasionally contains isolated or small groups of sclereids (fig. 4).

\section{THE FROND}

Petiole traces demonstrating a $2 / 5$ phyllotaxy occur infrequently in the cortex of stems (TAYLOR and STOCKEY 1976). Initially the petiole trace diverges from the stele as an ovoid group of ca. 20 tracheids and enters the cortex where it expands tangentially to form a V-shaped bundle with two to three groups of abaxial protoxylem. The petiole trace remains in the cortex for some distance and gradually diverges into a large clasping petiole base that surrounds over one-half the stem diameter. Distally, the petiole is first V-shaped in outline as a result of large adaxial projections (fig. 1). Eventually these give rise laterally to the primary pinnae (fig. 8). Between the diverging primary pinnae, the rachis may become square in outline but again produces adaxial projections prior to pinna trace divergence.

Oval to $\mathrm{V}$-shaped primary pinna traces (figs. 2, $3,13)$ are produced by the petiole at an acute angle in an alternate to subopposite arrangement (fig. 8). Primary pinnae distally become $\mathrm{V}$-shaped and may exhibit prominent abaxial trichomes like those of the stem (fig. 9). Primary pinnae produce secondary pinnae (figs. 2, 9-11) that bear ultimate laminar segments in an alternate arrangement. Laminar pinnules (figs. 9 at top, 13) are two-, three-, or four-lobed, and are vascularized by traces containing 8-10 tracheids (fig. 26). Laminae are up to $120 \mu \mathrm{m}$ thick in cross section and show no differentiation into palisade and spongy layers (figs. 18-23).

Vascular strands are composed of tracheids with scalariform to pitted wall thickening patterns. In many specimens, foliage is well preserved, and in cross section, xylem is surrounded by prominent, thin-walled cells that probably represent elements of the phloem (figs. 19, 20). Sieve cells have not been positively identified.
Fronds of Microspermopteris are characterized by a simple, parenchymatous mesophyll with few distinguishing features. However, in ca. $50 \%$ of the specimens studied, resinous cells are scattered throughout the foliar tissue. Although specimens containing these cells occur together with those that lack this feature, the two histological types have not been observed to intergrade within an individual frond.

\section{AXILLARY BRANCHES}

Branches occur in the axils of fronds. Typically they can be traced only for a short distance distally. Some branches exhibit a small, inconspicuous primary body surrounded by prominent radial files of secondary xylem (fig. 1). The primary body of one specimen of this type increases in size distally until ca. 12 metaxylem elements are visible in the stele. In other specimens the primary body is $170 \mu \mathrm{m}$ in diameter, and secondary xylem is lacking (fig. 4). Steles are surrounded by a characteristic cortex of thin-walled parenchymatous tissue containing individual or groups of sclereids (fig. 4). Axes are characterized by an irregular, wavy margin and frequently produce scalelike leaves in a tight helix (fig. 4).

Other axillary branches demonstrate a comparatively large primary body $(270 \mu \mathrm{m})$ with a poorly differentiated stele containing a large portion of parenchymatous tissue and groups of a few xylem, or possibly procambial, strands (figs. 5-7). At this level the margin is relatively smooth. Flattened bud scales similar to those of Callistophyton (DELEVORYAS 1956; ROTHWELL 1975) are $1.1 \mathrm{~mm}$ wide in cross section and possess a central vascular strand and a distinct epidermis (figs. 5-7, at left). Since the axis of this specimen is broken or abraded on one side, it is not possible to determine the overall arrangement and number of bud scales. Distally the margin becomes slightly irregular and appears to produce small projections (fig. 7 , top). These may represent immature appendages, cortical flanges, or primordia. Prominent resinous cells are present throughout the tissue (figs. 5-7). No evidence has been found for the attachment of reproductive organs to axillary branches.

It should be noted that specimens illustrated by BAXTER as branch traces (BAXTER 1949, plate 2. figs. 1-3; BAXTER 1952, fig. 1) and distichous branches (BAXTER 1952, fig. 2) are more similar to foliar traces and foliar members of our material, respectively, than to axillary branch traces or axillary branches.

$6057 \mathrm{C}$ top b no. $474, \times 43$. Figs. 5-7. Sequence of oblique-cross sections of axillary branch with poorly differentiated stele. thought to represent immature bud. All $\times 57$. Fig. 5, Oblique-cross section. Note poorly developed strands of stele (st) and flattened bud scale (left). Specimen has been abraded at right. 1061 B bot. no. 545. Fig. 6. More distal section. Arrow indicates bud scale trace. $1061 \mathrm{~B}$ bot. no. 552. Fig. 7, Distalmost section. At this level bud scale (b) has diverged from axis (at left). Note resinous cells $(r)$ at top. 1061 B bot. no. 557. 


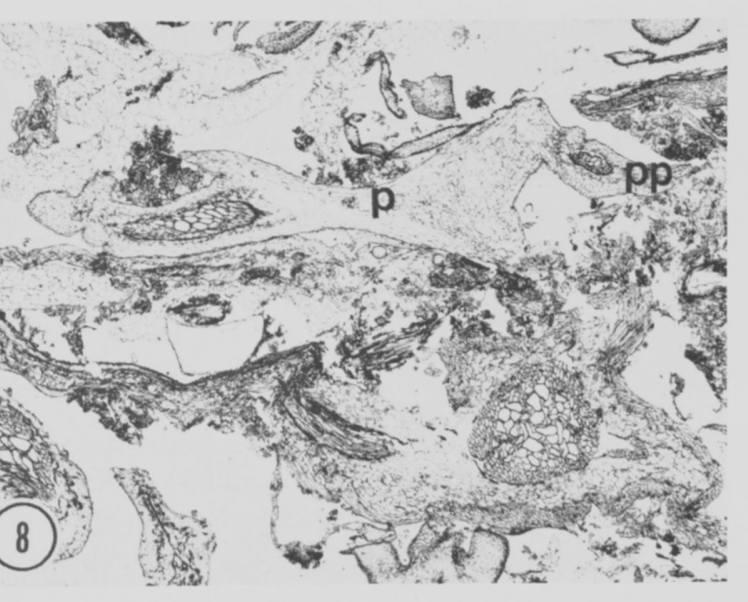

1.4.

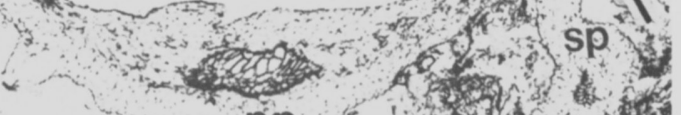
(9) $p p$ p ous of ow

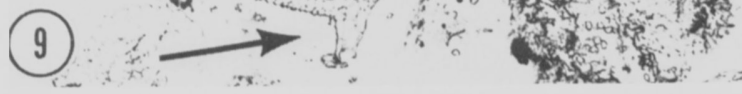

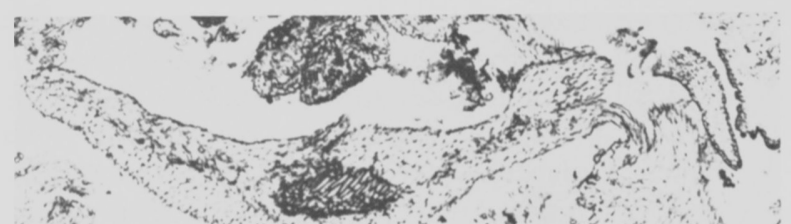

(10) -1 4

(2)

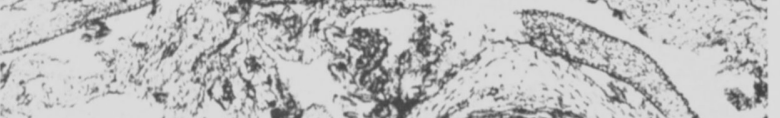

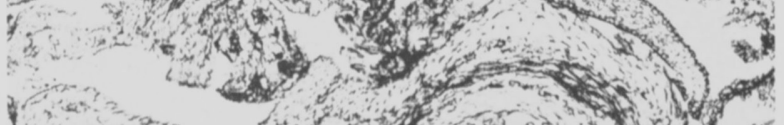
N

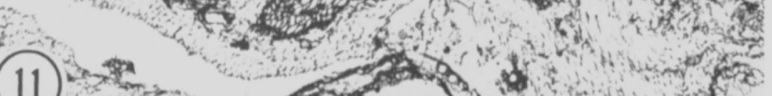

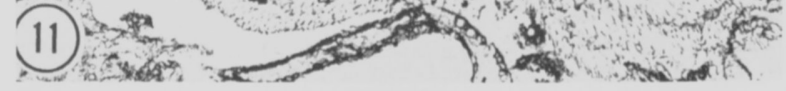

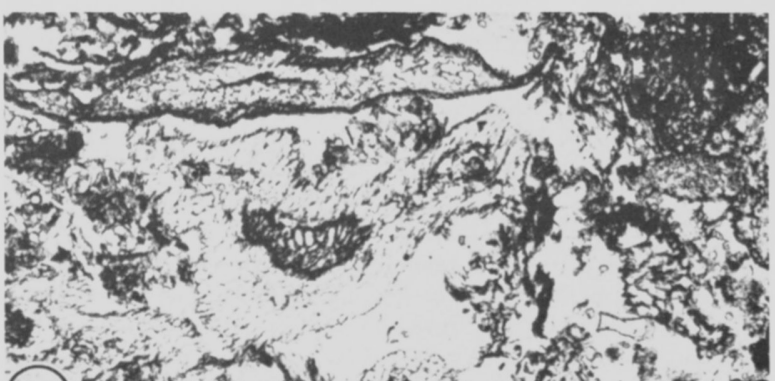

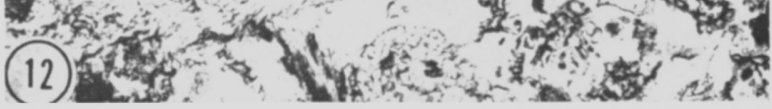
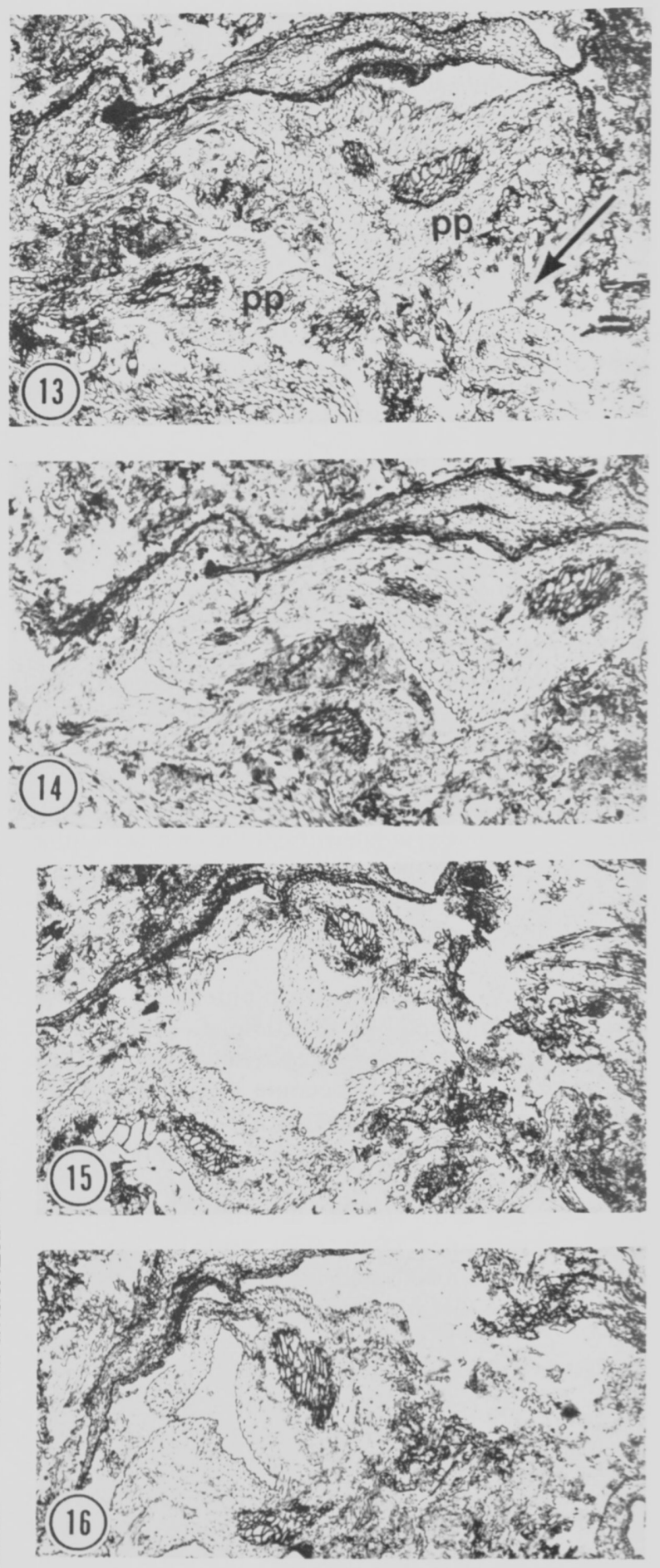

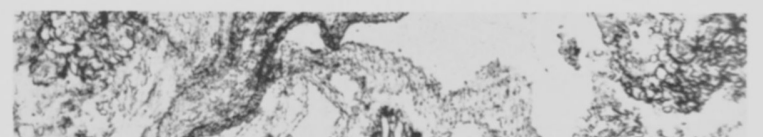

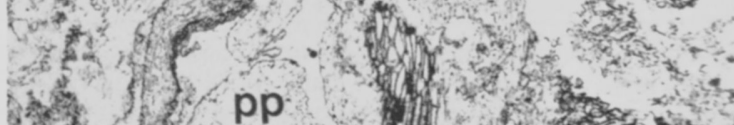

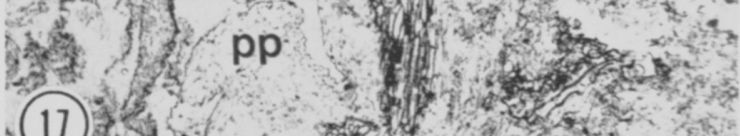

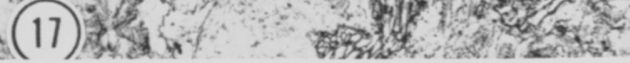




\section{Discussion}

\section{PALEOZOIC PTERIDOSPERM FOLIAGE: LYGINOPTERIDS}

Our interpretation of frond architecture of $\mathrm{Mi}$ crospermopteris is based on relatively small, delicate foliar segments that represent a frond less complex in organization than other lyginopterid fronds: Lyginopteris (BLANC-LOUVEL 1966); Schopfiastrum (ROTHWELL and TAYLOR 1972; STIDD and PHILlips 1973), and Heterangium (SHADLE and STIDD 1975). Although the small size might in part reflect the limited sample size and fragmentary nature of the material, Microspermopteris is known only from stems that did not exceed $1.1 \mathrm{~cm}$ in diameter. Perhaps fronds produced more proximally or on more robust plants may have been somewhat larger, but all evidence suggests that Microspermopteris represents a relatively small plant with a frond that was not extensive.

The frond architecture of Microspermopteris differs from that of other lyginopterids in several ways. The petiole of Microspermopteris remains V-shaped distal to its divergence from the stem, rather than becoming rounded or oval in outline as is common in other lyginopterids. Primary pinnae are produced directly from adaxial projections of the petiole. The petiole is vascularized by a single strand throughout, while in some lyginopterid taxa with larger, more complex fronds, particularly Heterangium (SHADLE and STIDD 1975), petioles appear vascularized by multiple strands. Perhaps most important, Microspermopteris lacks a major dichotomy of the petiole prior to the production of primary pinnae, a feature of all other lyginopterid foliage except other small forms such as Johnhallia (STIDD and PHILLIPS 1982) and the sterile and fertile foliage type Feraxotheca (MILLAY and TAYLOR 1977, 1978).

Based on serial sections, the reconstructed frond of Microspermopteris most closely resembles a Sphenopteris-like compression form (figs. 24-25). Like the Sphenopteris foliage, ultimate pinnules are laminar, rounded, and variably two-, three-, or fourlobed. However, because of its limited size, it is unlikely that the Microspermopteris frond contained as many laminar segments as a typical pinnate Sphenopteris frond. The occurrence of $\mathrm{Mi}$ crospermopteris in the Carboniferous compression flora has not been reported, but, in that preservational state, specimens would in all probability be inconspicuous and easily overlooked in the field or mistaken for fragments of larger fronds.

A number of lyginopterid stems has been correlated with respective foliage types. These include Lyginopteris oldhamia (BLANC-LOUVEL 1966), Schopfiastrum decussatum (ROTHWELL and TAY. LOR 1972; STIDD and PHILLIPS 1973), Heterangium americanum (SHADLE and STIDD 1975), Heterangium sp. (JENNINGS 1976), and possibly H. kukukii (HIRMER 1933). It is evident from such studies that most lyginopterids share similar morphological features. In all known forms, fronds with a characteristic architecture bear either Sphenopteris-, Mariopteris-, or Rhodea-type foliage. Microspermopteris can be distinguished from Lyginopteris, Schopfiastrum, and Heterangium on the basis of frond architecture alone, but additional histological features, particularly those of the ultimate laminar pinules, are characteristic for each form.

Foliage of Lyginopteris has $\mathrm{M}$ - or $\mathrm{U}$-shaped petioles and capitate glands throughout the frond. $L y$ ginopteris oldhamia has been correlated with the compression frond Sphenopteris hoeninghausii or the permineralized frond Rachiopteris aspera (TAYLOR and MILLAy 1981). Histological features of the lamina include a homogeneous mesophyll with palisade and spongy layers, prominent vein sheaths, and inflated vein tips. Distinctive foliar features of Schopfiastrum include large petioles with a toothed abaxial surface and $Y$-shaped vascular trace throughout the frond (ROTHWELL and TAYLOR 1972). Ultimate laminar pinnules are characterized in cross section by veins with parenchymatous bundle sheaths alternating with lacunae and are thought to be most similar to Mariopteris or Sphenopteris foliage (Rothwell and TAYLOR 1972; STIDD and PhILlipS 1973).

In the genus Heterangium, three types of foliage have been described in association with stems. HIRMER (1933) pointed out the association of neuropterid pinnules with $H$. kukukii stems: the significance of this association was questioned by SHADLE and STIDD (1975). The frond of H. americanum has been described with four orders of branching, including a $\mathrm{W}$-shaped petiole that dichotomizes distally (SHADLE and STIDD 1975). Pinnules may be one-, three-, or five-lobed and are characterized anatomically by mesophyll differentiated into spongy and palisade layers. Vascular strands are inconspicuous, and a dark-walled spongy

FIGS. 8-17.-Microspermopteris aphyllum. Fig. 8, Petiole $(p)$ showing attachment to a primary pinna $(p p)$. A second primary pinna diverged from this specimen to the upper left in more distal sections. Stem at bottom is not in attachment to petiole. 6057 $\mathrm{C}$ top b no. $110, \times 14$. Figs. 9-17, Higher-magnification, serial sections of primary pinna and its pinnules. Fig. 9, Primary pinna with abaxial trichomes (arrow at bottom), secondary pinna (sp), and laminar pinnule (arrow at top). $6057 \mathrm{C}$ top b no. 130 . All

40. Figs. 10, 11. Attachment of secondary pinna (at right). Fig. 10, $6057 \mathrm{C}$ top b no. 151. Fig. 11, $6057 \mathrm{C}$ top b no. 173. Fig. 12, Primary pinna at level where no secondary pinnae are diverging. $6057 \mathrm{C}$ top b no. 232. Figs. 13-16. Primary pinna is twisted in the matrix such that it is sectioned twice. Fig. 13, Primary pinna producing a second secondary pinna trace (to left), laminar pinnule (arrow at right bottom). $6057 \mathrm{C}$ top b no. 245. Fig. 14, $6057 \mathrm{C}$ top b no. 261. Fig. 15, $6057 \mathrm{C}$ top b no. 293. Fig. 16, $6057 \mathrm{C}$ top b no. 311. Fig. 17, Level at which pinna is bent. $6057 \mathrm{C}$ top b no. 315 
3) The

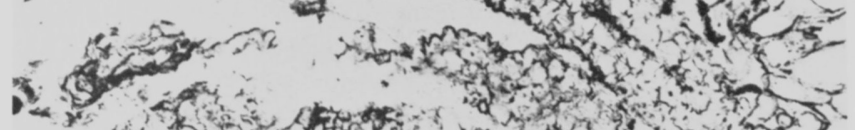

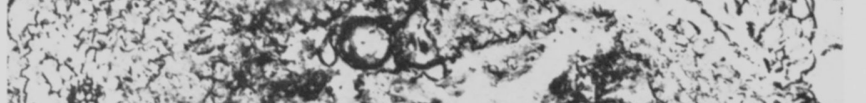

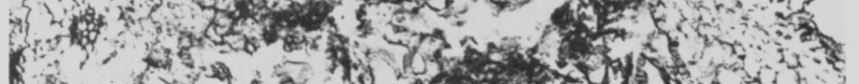

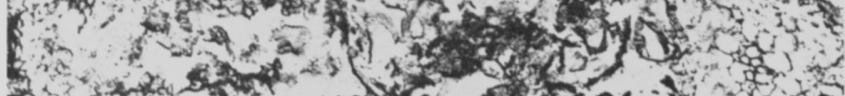
R. (18) $, 400,40,0$

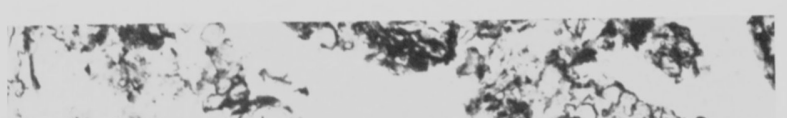

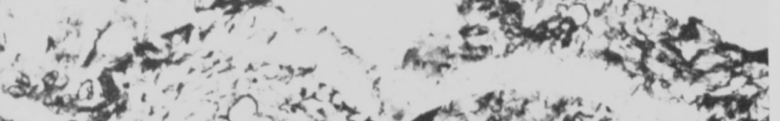
on orita 1. 40 -

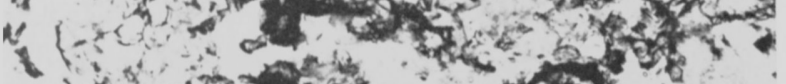

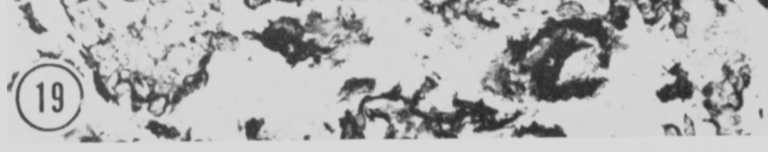
-

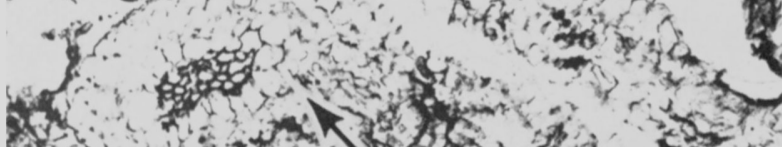

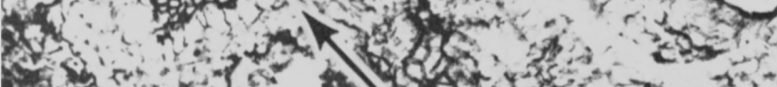
(20) 3

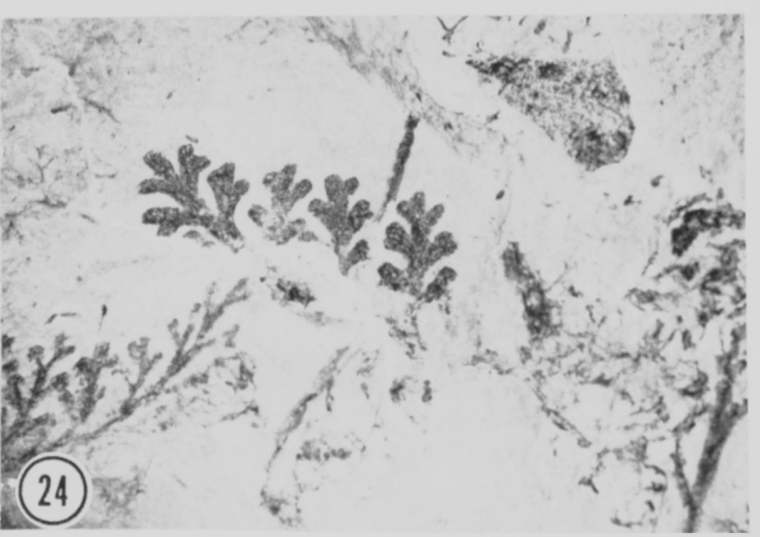

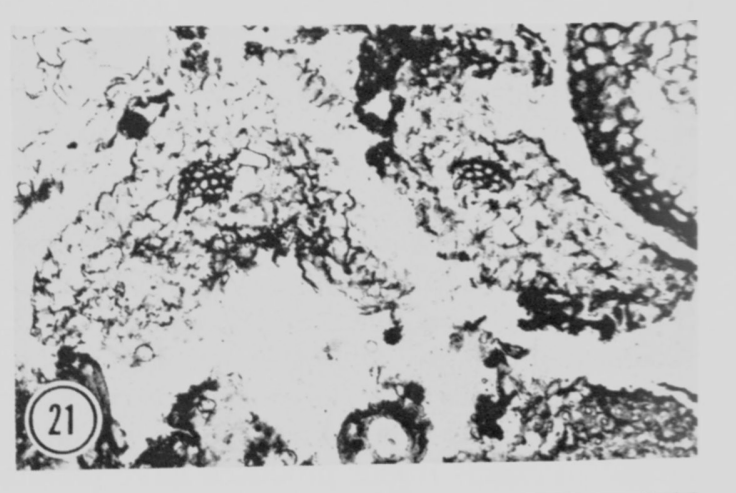

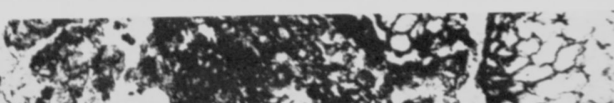
Mand
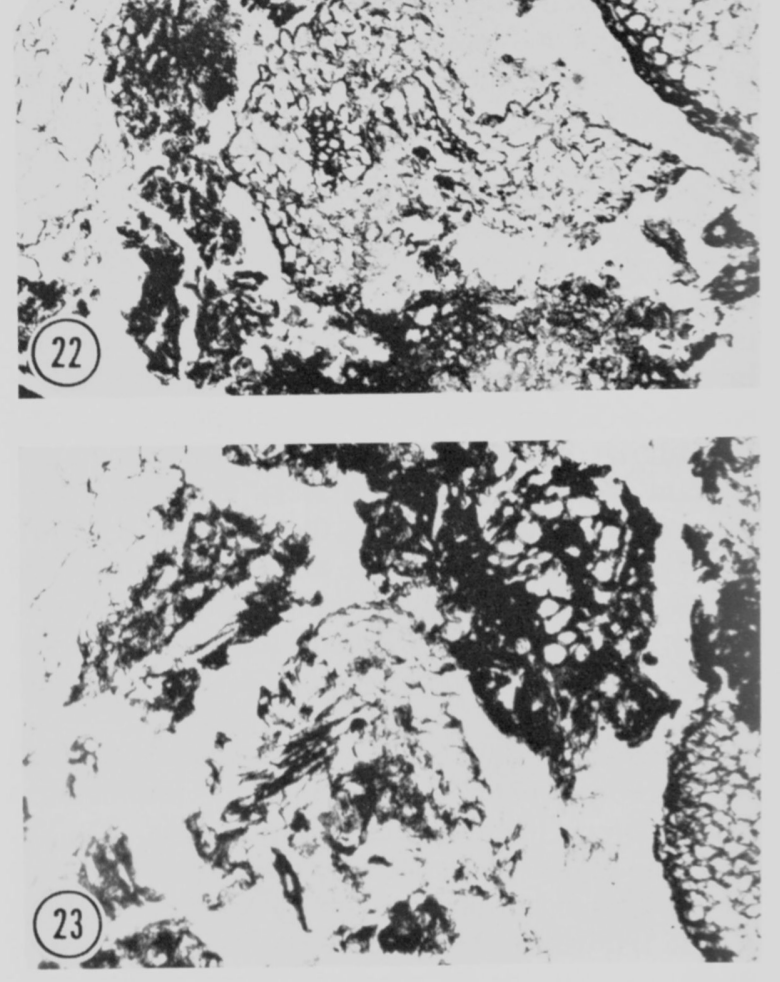

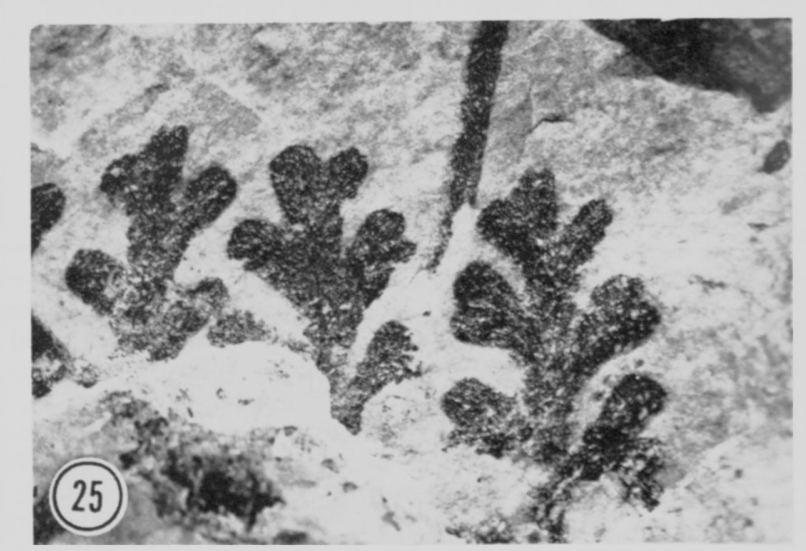


parenchyma is present. Comparison with compression taxa is closest with Sphenopteris obtusiloba Brongniart (SHADLE and STIDD 1975). A second unnamed Heterangium species (JENNINGS 1976) exhibits foliage of the Rhodea type.

Although not correlated with its stem, the sterile and fertile foliage of Feraxotheca has also been well characterized (MILLAY and TAYLOR 1977, 1978) and is quite unlike Microspermopteris. Foliage of Feraxotheca is characterized by a $\mathrm{C}$-shaped vascular strand, prominent resin canals abaxial to the vascular strand, and differentiated mesophyll with compact palisade-like cells. Vascular strands flare prominently at the tips.

Finally, the genus Johnhallia was proposed for a distinctive eustelic pteridosperm (STIDD and PHILlips 1982). Although the plant was not assigned to any pteridosperm family, it bears a number of similarities with the Callistophytales. Its foliage type is distinct, and, although ultimate laminar segments are equally small, delicate, and histologically simple, they are more flattened and shinglelike in cross section than are those of Microspermopteris (STIDD and PHILLIPS 1982).

When found isolated, pinnules of Microspermopteris differ from the above types through a combination of features of size, shape, and histology. Ultimate laminar pinnules of Microspermopteris are smaller than most of the other forms. Their simple parenchymatous histology differs markedly from most other foliage types (with the exception of Johnhallia; STIDD and PHILLIPS 1982) that are generally differentiated into palisade and spongy mesophyll; the prominent $\mathrm{V}$-shaped vascular strand is distinctive. Although scattered resinous cells are sometimes present in Microspermopteris foliage, there are no precisely placed canals directly abaxial to vascular strands, as in fertile and sterile foliage of Feraxotheca.

In addition to its relatively rare occurrence, the foliage of Microspermopteris has been difficult to characterize because of the sinuous, irregular orientation of the plant in the coal ball matrix. Such problems with studying Microspermopteris undoubtedly influenced early reconstructions of it as a plant with prominent right-angled branching (BAXTER 1949, plate 5). Frond pinnae tend to assume a tortuous course, making the proximal-distal

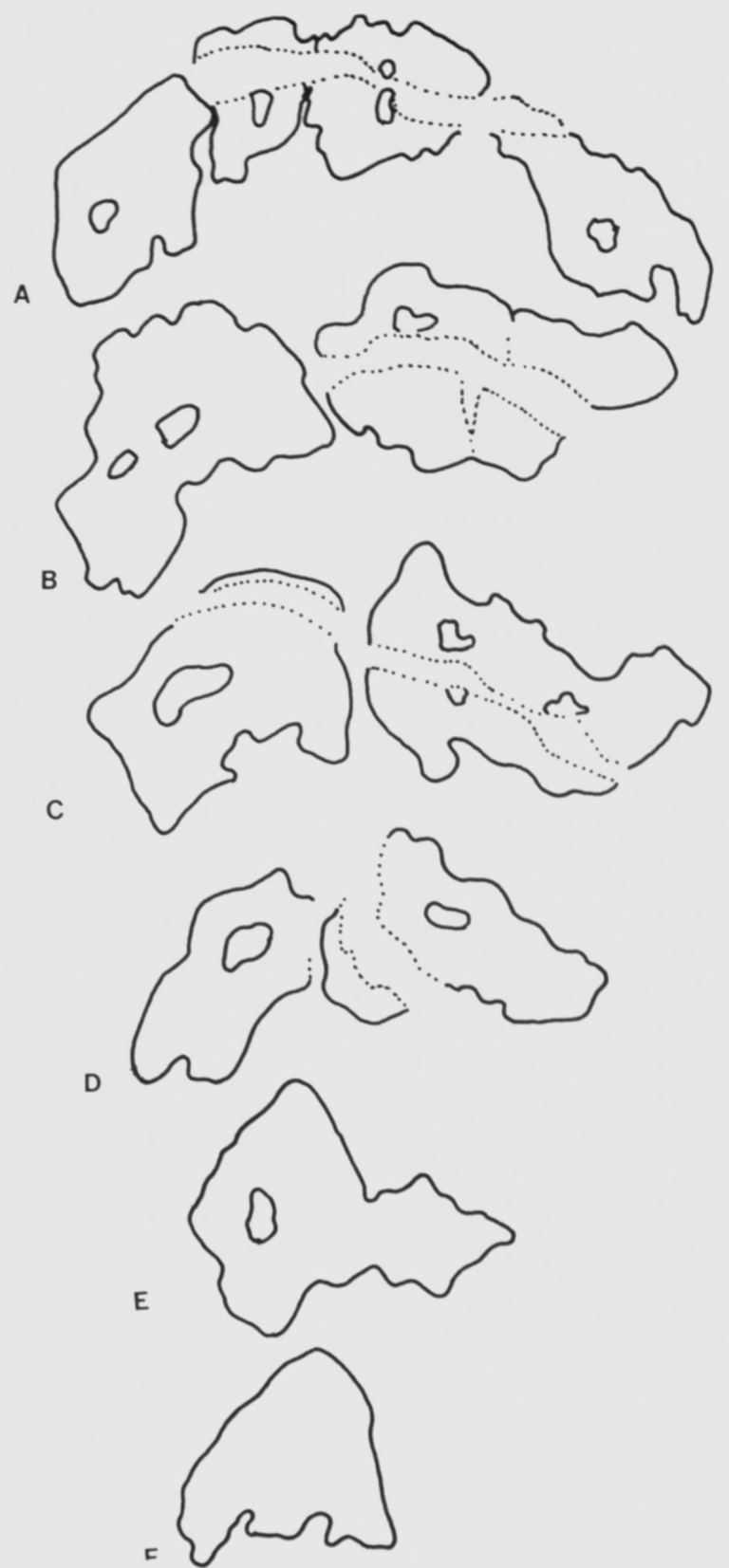

FIG. 26. - Line diagrams of ultimate laminar pinnules illustrated in figs. 18-23. See descriptor for figs. 18-23 for details. $A=$ fig. $18, B=$ fig. $19, C=$ fig. $20, D=$ fig. $21, E=$ fig 22. $F=$ fig. 23 . All $\times 97.5$

FIGS. 18-25.-Figs. 18-23, Microspermopteris aphyllum. Sequence of cross sections through ultimate laminar pinnules showing morphological and histological features. This sequence is also represented by the line diagrams in fig. 26 to clarify positions of vascular tissue and lobes that are somewhat distorted by the mineral crack in figs. $18-21$ (at top). All $\times 125$. Fig. 18 (=fig. 26A), Distalmost level; four-lobed, each lobe vascularized by a single trace. $6057 \mathrm{C}$ top b no. 95 . Fig. 19 (=fig. 26B). More proximal level; laminae are divided into two or possibly three lobes. Lobe at left with two traces, vascular trace supplying lobe at far right is out of section. $6957 \mathrm{C}$ top b no. 145. Fig. 20 (=fig. 26C), More proximal level, two-lobed with three vascular strands. Note large thin-walled cells in position of phloem (arrow). $6057 \mathrm{C}$ top b no. 157. Fig. 21 (=fig. 26D), More proximal level, two lobes, each vascularized by a single strand. $6057 \mathrm{C}$ top b no. 191. Fig. 22 (=fig. 26E), More proximal level, one lobe prior to division, with one vascular strand in section. $6057 \mathrm{C}$ top b no. 219. Fig. 23 (=fig. 26F), Most proximal level, oblique. near base of pinnule. Vascular strand is oblique. $6057 \mathrm{C}$ top b no. 232. Figs. 24, 25, Sphenopteris sp. compression; illustrated as a suggested morphological type for Microspermopteris laminar pinnules. P32-937. fig. 24 , $\times 2.5 ;$ fig. $25, \times 6.2$ 
relationships of individual frond members difficult to establish. The small size and inconspicuous parenchymatous histology of many fronds have further caused confusion with the simple leaves of lycophytes in the same matrix. Previous assumptions that the frond of Microspermopteris would exhibit a typical seed fern pattern may have caused its confusion with an unnamed revolute foliage form in the same matrix that has been figured as Microspermopteris foliage (Lewis Creek; TAYLOR and MILLAY 1981, fig. II, 4, 5). This latter form is generally poorly preserved and inconspicuous but contains prominent vein sheaths between the upper and lower epidermis that are lacking in known Microspermopteris foliage. Considering the lack of intergradation of histology and organic attachment to known Microspermopteris foliage, this second foliage form cannot be equated with the present material.

\section{RELATIONSHIP OF MICROSPERMOPTERIS and Heterangium}

Among other lyginopterid taxa, Microspermopteris most closely resembles the genus Heterangium. Prior to the present description, it was unclear whether Microspermopteris represented a separate plant or more distal segments of some Heterangium species. The two forms were confused because of their apparent intergradation in stelar anatomy, especially in instances where steles were crushed and decorticated. Because of the paucity of specimens suitable to rigorous investigation, a complete understanding of the protosteles of Microspermopteris and of most species of Heterangium (with the exception of $H$. kukukii; HIRMER 1933) has not been possible. Many species of Heterangium, for instance, are based upon superficial stelar appearance in transverse section, an appearance that in many specimens is drastically altered with crushing. Features traditionally used in delimiting the concept of the protostele include relative positions and amounts of metaxylem and ground tissue. Protoxylem architecture, although more difficult to discern, may be more diagnostic. Until stelar anatomy is better understood, the phylogenetic significance of protostelic pteridosperms such as Microspermopteris and Heterangium (BECK and STEIN 1985) remains conjectural.

Additional criteria for distinguishing Microspermopteris and Heterangium have included the presence of one or two leaf traces and several minor anatomical distinctions, such as the relative amounts of parenchyma in the stele and the resulting shape of tracheids in cross section and the configuration of the vascular rays. These distinctions were difficult to employ, particularly since some species of Heterangium (the "Euheterangium" group of SCOTT [1917]) exhibited a single vascular trace to the petiole. TAYLOR and STOCKEY (1976) suggested rather despairingly that "until reproductive organs are found, petiole anatomy will continue to be the distinguishing character." Nevertheless, although the reproductive organs of Microspermopteris have yet to be characterized, additional information about the vegetative features provides a basis for distinguishing between Heterangium and Microspermopteris.

Heterangium exhibits a characteristic frond architecture (SHADLE and STIDD 1975) with a large multivascularized petiole containing vascular tissue that becomes $\mathrm{W}$-shaped prior to dichotomization. Primary and secondary pinnae are borne on the rachis in a subopposite to alternate fashion, and fronds are pinnate. The frond organization is unlike that in leaves of Microspermopteris, which are much smaller and have no dichotomy or complex pinnate organization to their fronds. Although branching stems are known, Heterangium is not known to produce axillary branches like those of Microspermopteris. The variability in primary body size of Microspermopteris axillary branches, amount of secondary xylem, and variability in histological features may be totally attributable to a variety of ontogenetic stages or may reflect differences in vegetative branches and those that bear reproductive structures.

A number of histological features separates $\mathrm{Mi}$ crospermopteris from Heterangium. Although many lyginopterids are characterized by capitate glands, Microspermopteris exhibits peculiar multicellular trichomes, as well as irregular cortical flaps of tissue that are either absent or not so well developed among other lyginopterids. Conversely, although occasionally individual cells or small groups of sclerotic cells may occur in Microspermopteris, the organized, tangentially produced sclerotic nests of Heterangium cortex are absent.

\section{RELATIONSHIP OF MICROSPERMOPTERIS AND SYNCRAMA}

Several authors (e.g., PHILlips 1980) have suggested that the poorly known monotypic genus Syncrama Holden probably represents a species of Microspermopteris. The taxon is known from two axes on a single thin section from the Lancashire Coal Measures in Britain, collected at Shore near Littleborough (HOLDEN 1954). A reinvestigation of the type specimen of Syncrama allowed us to compare this material to Microspermopteris. Each of the two axes is of comparable size to small stems of Microspermopteris (ca. $0.8 \mathrm{~mm}$ in diameter) and displays five prominent cortical arms, or ridges, resulting in a distinctive stellate shape (HOLDEN 1954, plate 22, fig. 1). HoLDEN suggested the ridges might represent decurrent petiole bases, but the small size of stems, the regularity of ridges with and without vascular traces, and their resemblance to those of Microspermopteris suggest they are com- 
parable structures. Whether cortical ridges in both taxa are real anatomical structures or the result of shrinkage of internal tissues is not always clear in specimens with disrupted tissue. However, many small Microspermopteris stems with flanges exhibit good tissue continuity, suggesting that at least some axes had irregular margins.

The stele of one specimen of Syncrama is dissected into three wedges by parenchymatous plates, while the other is dissected into six groups, both in a manner similar to the pentarch stele of $\mathrm{Mi}$ crospermopteris. However, steles of Syncrama are mesarch, while those of Microspermopteris are typically exarch. Perhaps the most distinctive feature of Syncrama that distinguishes it from Lewis Creek specimens of Microspermopteris is the differentiation of an outer cortical rind of thickened, perhaps sclerotic, cells. In this regard the British material is similar to specimens described by BAXTER (1952) as M. aphyllum var. kansensis, from the Fleming coal of southeastern Kansas and later synonymized by TAYLOR and STOCKEY (1976) with M. aphyllum.

Although specimens of Syncrama are at least superficially quite similar to Microspermopteris, the genus is very incompletely known. Possible synonymies with Microspermopteris aphyllum, with the material described as $M$. aphyllum var. kansensis (sensu BAXTER), or recognition of Syncrama as a distinctive plant await the discovery and investigation of additional material.

\section{Plant RECONSTRUCTION}

Although BAXTER (1949) interpreted Microspermopteris as a primitive plant, its phylogenetic position as an intermediate between the psilophytes and the seed plants now seems unlikely. The prominent multicellular trichomes, which resemble enations in BAXTER's (1949, plate 5) reconstruction, occur on both stem and frond members, and the presence of leaves and axillary branches establishes Microspermopteris as a plant too sophisticated to be considered in psilophytic or even progymnospermous terms. However, because the plant is relatively small and its reproductive parts have not been discovered, the status of the taxon as a lyginopterid might be questioned. Whether the plant bore its seeds and pollen organs on the small frond or on axillary branches, the fertile parts themselves must have been at least as small as, e.g., some associated lyginopterid seeds reported from this locality (Conostoma chappellicum, $2.8 \mathrm{~mm}$ long; StubBLEFIELD and Rothwell 1980). The plant could not support either large pollen organs or ovules on any of the laminar segments that we examined. In addition, some species of Constoma (e.g. C. villosum, Rothwell and EGGERT 1970) are characterized by conspicuous integumentary flanges or trichomes similar to those of Microspermopteris

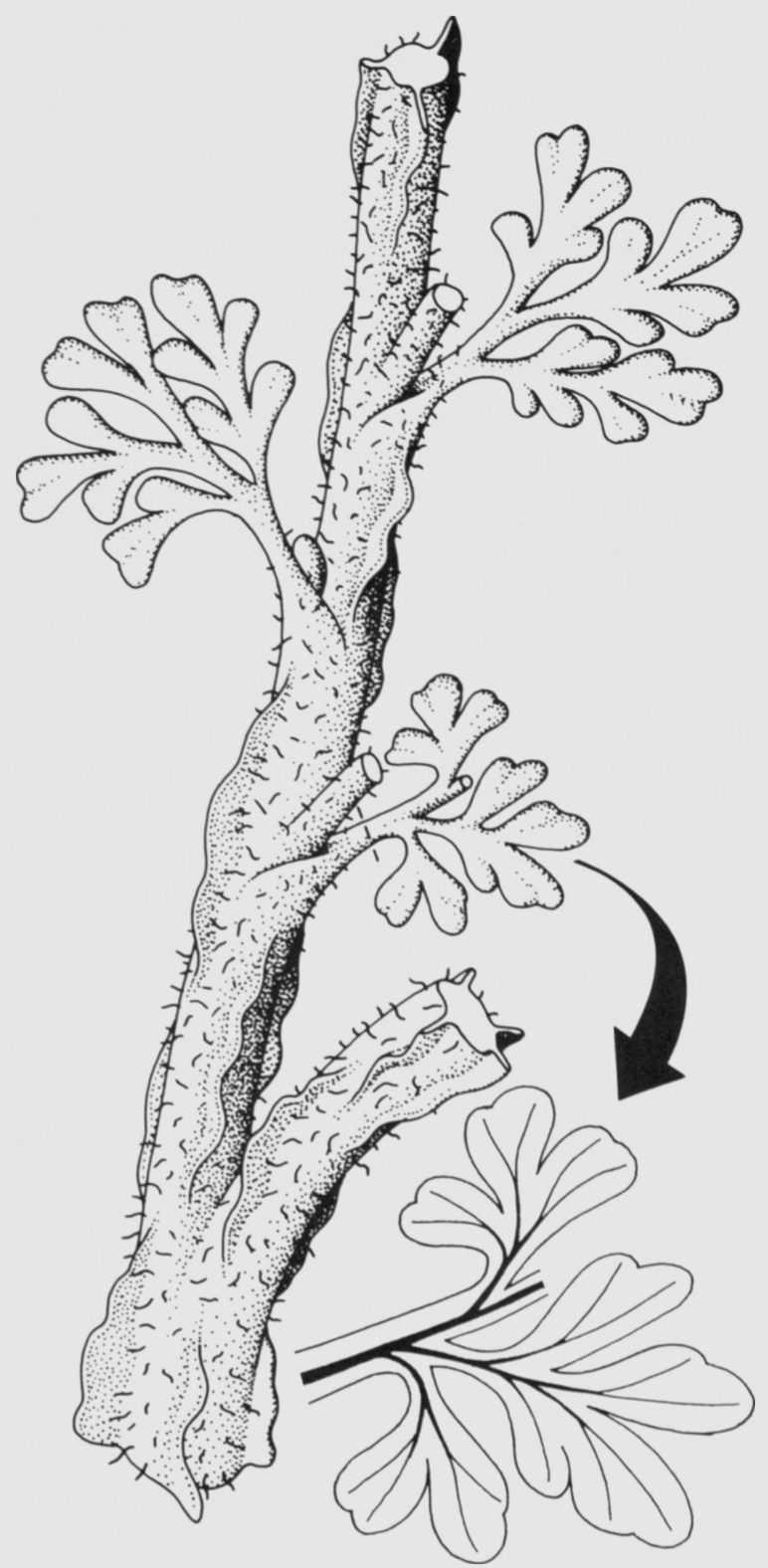

FIG. 27.-Reconstruction of segment of a Microspermopteris plant based on interpreted features. Appendages have been omitted from axillary branches save for bud scales (at upper left). Frond at lower right is reconstructed from serial sections illustrated in figs. $8-17$; inset at arrow indicates vascularization. Complete fronds (at top) are conjectural. A liana, shrublike, or scrambling plant habit are all consistent with data, $\times 8$.

stems and foliage. While these seeds have not yet been found in organic attachment to vegetative organs, they are regarded as lagenostomalean seeds.

Microspermopteris exhibits many anatomical features of lyginopterids (fig. 27) and, as yet, possesses no features that suggest a position as a fern, progymnosperm, or member of any other group. Until conclusive evidence for its placement in another group is found, Microspermopteris fits most 
appropriately in the Lyginopteridaceae. The absence of attached or obviously associated reproductive structures among the studies of vegetative material suggests that this plant may have reproduced primarily vegetatively while growing under favorable swamp conditions and produced seeds only when conditions were poor. Its relatively small size and presumably vinelike, shrubby, or procumbent habit may well have filled a unique niche in the Carboniferous coal swamp.

\section{Acknowledgments}

We thank Mr. David M. Dennis for illustrations, and Dr. C. R. Hill, Mr. H. Pearson, and Mr. C. Shute, British Museum (Natural History), for locating and lending to us the type specimen of Syncrama Holden. This work was supported by National Science Foundation grants BSR-8402813 and BSR-8410399.
BAXter, R. W. 1949. Some pteridosperm stems and fructifications with particular reference to the Medullosae. Ann. Mo. Bot. Gard. 36:287-352.

1952. The coal age flora of Kansas. I. Microspermopteris aphyllum var. kansensis var. nov. Trans. Kans. Acad. Sci. 55:101-103

BeCK, C. B., and W. E. SteIn, JR. 1985. Eustelic protosteles in early seed plants? Am. J. Bot. 72:889 (Abstr.).

Blanc-Louvel, C. 1966. Étude anatomique comparée des tiges et des pétioles d'une ptéridospermée du Carbonifère du genre Lyginopteris Potonié. Mém. Mus. Natl. Hist. Nat., N.S., 18: $1-103$

Delevoryas, T. 1956. The shoot apex of Callistophyton poroxyloides. Contrib. Mus. Paleontol. Univ. Mich. 12:285299.

Good, C. W., and T. N. TAYLOR. 1970. On the structure of Cordaites felicis Benson from the lower Pennsylvanian of North America. Palaeontology 13:29-39.

HiRmer, M. 1933. Zur Kenntnis der strukturbietenden Pflanzenreste des jüngeren Paläozoikums. Palaeontographica 78B:57-133

Holden, H. S. 1954. Some features in the morphology of a hitherto undescribed stem from the Lancashire Coal Measures. Bot. J. Linn. Soc. 55:313-317.

JENNINGS, J. R. 1976. The morphology and relationships of Rhodea, Telangium, Telangiopsis and Heterangium. Am. J. Bot. 63:1119-1133.

MAHAFFY, J. M. 1975. Morphology of Microspermopteris and occurrences in middle Pennsylvanian coal balls. Bot. Soc. Am. Abstr. p. 22.

Millay, M. A., and T. N. TAYLOR. 1977. Feraxotheca gen. $\mathrm{n}$., a lyginopterid pollen organ from the Pennsylvanian of North America. Am. J. Bot. 64:177-185.

1978. Fertile and sterile frond segments of the lyginopterid seed fern Feraxotheca. Rev. Palaeobot. Palynol. 25: $151-162$.

Oliver, F. W., and D. H. ScotT. 1904. On the structure of the Palaeozoic seed Lagenostoma lomaxi with a statement of the evidence upon which it is referred to Lyginodendron. Philos. Trans. Soc. Lond., Ser. B., 197:193-247.
PHILLIPS, T. L. 1980. Stratigraphic and geographic occurrences of permineralized coal-swamp plants-Upper Carboniferous of North America and Europe. Pages 25-92 in D. L. DiLCHER and T. N. TAYLOR, eds. Biostratigraphy of fossil plants. Dowden, Stroudsburg, $\mathrm{Pa}$.

Rothwell, G. W. 1975. The Callistophytaceae (Pteridospermopsida). I. Vegetative structures. Palaeontographica 151B: $171-196$.

Rothwell, G. W., and D. A. Eggert. 1970. A Conostoma with a tentacular sarcotesta from the upper Pennsylvanian of Illinois. BоT. GAZ. 131:359-366.

Rothwell, G. W., and T. N. TAYlor. 1972. Carboniferous pteriodosperm studies: morphology and anatomy of Schopfiastrum decussatum. Can. J. Bot. 50:2649-2658.

Scott, D. H. 1917. The heterangiums of the British Coal Measures. J. Linn. Soc. 44:59-105.

Shadle, G. L., and B. M. Stidd. 1975. The frond of Heterangium. Am. J. Bot. 62:67-75

Stidd, B. M., and T. L. Phillips. 1973. The vegetative anatomy of Schopfiastrum decussatum from the middle Pennsylvanian of the Illinois Basin. Am. J. Bot. 60:463-474

1982. Johnhallia lacunosa gen. et sp. n.: a new pteridosperm from the middle Pennsylvanian of Indiana. J. Paleontol. 56:1093-1102.

Stubblefield, S. P., and G. W. Rothwell. 1980. Conostoma chappellicum $\mathrm{n}$. sp., lagenostomalean ovules from Kentucky. J. Paleontol. 54:1012-1016.

Stubblefield, S. P., T. N. Taylor, and C. P. Daghlian. 1982 Compressed plants from the lower Pennsylvanian of Kentucky (U.S.A.). I. Crossotheca kentuckyensis n. sp. Rev Palaeobot. Palynol. 36:197-204.

TAYlor, T. N., and M. A. Millay. 1981. Morphological variability of Pennsylvanian lyginopterid seed ferns. Rev. Palaeobot. Palynol. 32:27-62.

TAYLOR, T. N., and R. A. Stockey. 1975. The morphological nature of Microspermopteris. Bot. Soc. Am. Abstr. pp. 2526.

1976. Studies of Paleozoic seed ferns: anatomy and morphology of Microspermopteris aphyllum. Am. J. Bot. 63:1302-1310. 